could indicate that this strong electrophile ${ }^{3 \mathrm{~b}}$ may be immediately trapped by the germole 2 , with loss of $\mathrm{CO}$, to give 1 , i.e. the germacyclopentenyl moiety $\eta^{3}$-coordinated to $\mathrm{Co}(\mathrm{CO})_{3}$. Precedents of these reactions have been reported in the action of dienes with metal hydrido complexes. ${ }^{14}$

(14) Schunn, R. A. In Transition Metal Hydrides, Muetterties, E. L. Ed.; Marcel Dekker: New York, 1971; p 216. Tolman, C. A. J. Am. Chem. Soc. $1970,92,6777,6785$.
Acknowledgment. We thank the Universitê P. Sabatier and the Centre National de la Recherche Scientifique (LCC) for the support of this work through ATUPS PCA and Internal ATP grants.

Supplementary Material Available: Listings of crystal data and data collection and refinement details, fractional atomic coordinates, bond distances and angles, and anisotropic thermal parameters (7 pages); a table of observed and calculated structure factors (18 pages). Ordering information is given on any current masthead page.

\title{
Synthesis and Solld-State Structure of $\left(\mathrm{Me}_{3} \mathrm{SI}\right)_{3} \mathrm{CGeCH}\left(\mathrm{SIMe}_{3}\right)_{2}$, a Monomeric Dlalkylgermylene
}

\author{
P. Jutzi, * A. Becker, H. G. Stammler, and B. Neumann \\ Fakultät für Chemie der Universität Bielefeld, D-4800 Bielefeld, Germany \\ Received January 25, 1991
}

Summary: The reaction of $\mathrm{Me}_{5} \mathrm{C}_{5} \mathrm{GeCH}\left(\mathrm{SiM}_{3}\right)_{2}$ with LiC$\left(\mathrm{SiMe}_{3}\right)_{3}$ affords $\left(\mathrm{Me}_{3} \mathrm{Si}\right)_{3} \mathrm{CGeCH}\left(\mathrm{SiMe}_{3}\right)_{2}$ (2), the first unsymmetrically substituted dialkylgermylene, which is stable at ambient temperature. In the solid state, the germylene 2 is monomeric, whereas Lappert's germylene $\left[\left(\mathrm{Me}_{3} \mathrm{Si}\right)_{2} \mathrm{CH}\right]_{2} \mathrm{Ge}$ (1) shows a dimeric structure with a $\mathrm{Ge}_{0}=\mathrm{Ge}$ double bond. Steric effects of the additional trimethylsilyl group in 2 are responsible for these drastic changes in the structure. The germylene $\mathrm{Me}_{3} \mathrm{SiCH}_{2} \mathrm{GeCH}\left(\mathrm{SiMe}_{3}\right)_{2}(3)$ decomposes at about $-20^{\circ} \mathrm{C}$.

Germylenes - the germanium analogues of carbeneshave been extensively studied during the last 15 years. ${ }^{1}$ Most of these compounds are unstable under normal conditions and thus have been used as reactive intermediates. $^{2}$ A noticeable stabilization is possible by using $\pi$-ligands ${ }^{3}$ or bulky ligands such as $-\mathrm{NR}_{2},-\mathrm{OR}$, or $-\mathrm{SR} ;{ }^{4}$ compounds of this type are stable at ambient temperature, and some of them are monomeric in the solid state and in the gas phase. In the class of dialkylgermylenes, the stable compound $\left[\left(\mathrm{Me}_{3} \mathrm{Si}\right)_{2} \mathrm{CH}\right]_{2} \mathrm{Ge}$ (1) was described in 1976 by Lappert and co-workers. ${ }^{5}$ This species has interesting structural features: It is a monomer in solution and in the gas phase ${ }^{6}$ and a dimer in the solid state. The

(1) (a) Petz, W. Chem. Rev. 1986, 86, 1019. (b) Lappert, M. F.; Rowe, R. S. Coord. Chem. Rev. 1990, 100, 267. (c) Barrau, J.; Escudiê, J.; Satgé, J. Chem. Rev. 1990, 90, 283.

(2) (a) Satgế, J. Pure Appl. Chem. 1984, 56, 137. (b) Neumann, W. P. Chem. Rev., in press. (c) Neumann, W. P. Nachr. Chem., Tech. Lab. 1982, 30, 190 .

(3) Jutzi, P. Adv. Organomet. Chem. 1986, 26, 217.

(4) (a) Harris, D. H.; Lappert, M. F. J. Chem. Soc., Chem. Commun 1974, 895. (b) Fjeldberg, T.; Hitchcock, P. B.; Lappert, M. F.; Smith, S. J.; Thome, A. J. J. Chem. Soc., Chem. Commun. 1985, 939. (c) Hitchcock,

P. B.; Lappert, M. F.; Samways, B. J.; Weinberg, E. L.; J. Chem. Soc. Chem. Commun. 1983, 1492. (d) Meller, A.; Gräbe, C. P. Chem. Ber. 1985, $118,2020$.

(5) (a) Goldberg, D. E.; Harris, D. H.; Lappert, M. F.; Thomas, K. M. J. Chem. Soc., Chem. Commun. 1976, 261. (b) Davidson, P. J.: Harris,

D. H.; Lappert, M. F. J. Chem. Soc, Dalton Trans. 1976, 2268.

(6) (a) Cowley, A. H.; Hull, S. W.; Nunn, C. M.; Power, J. M. J. Chem. Soc., Chem. Commun. 1988, 753. (b) Lappert, M. F.; Power, P. P. J. Chem. Soc., Dalton Trans. 1985, 51. (c) Fjeldberg, T.; Haaland, A.; Schilling, B. E. R.; Volden, H. V.; Lappert, M. F.; Thorne, A. J. J. Organomet. Chem. 1985, 280, C43. (d) Fjeldberg, T.; Haaland, A.; Schilling, B. E. R.; Lappert, M. F.; Thorne, A. J. J. Chem. Soc,, Dalton Trans. 1986, 1551 .

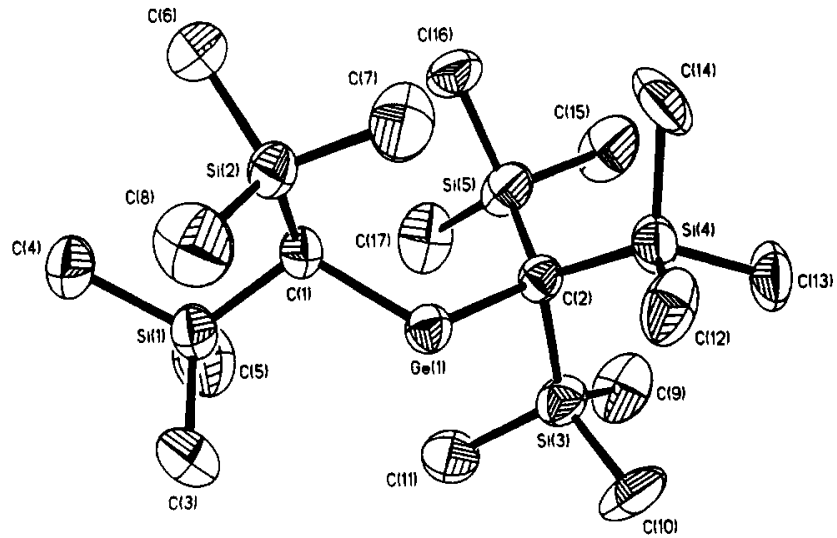

Figure 1. X-ray structure of $\left(\mathrm{Me}_{3} \mathrm{Si}\right)_{2} \mathrm{CHGeC}\left(\mathrm{SiMe}_{3}\right)_{3}(2)$. Selected bond distances $(\AA)$ and angles $(\mathrm{deg}): \mathrm{Ge}(1)-\mathrm{C}(1)=2.012$ (6), $\mathrm{Ge}(1)-\mathrm{C}(2)=2.067(4), \mathrm{Si}(1)-\mathrm{C}(1)=1.883(4), \mathrm{Si}(2)-\mathrm{C}(1)=$ $1.887(5), \mathrm{Si}(2)-\mathrm{C}(6)=1.857(9), \mathrm{Si}(3)-\mathrm{C}(2)=1.928(6), \mathrm{Si}(4)-\mathrm{C}(2)$ $=1.871(4), \mathrm{Si}(5)-\mathrm{C}(2)=1.881(6) ; \mathrm{C}(1)-\mathrm{Ge}(1)-\mathrm{C}(2)=111.3(2)$, $\mathrm{Ge}(1)-\mathrm{C}(1)-\mathrm{Si}(1)=115.2(3), \mathrm{Ge}(1)-\mathrm{C}(1)-\mathrm{Si}(2)=103.3(2), \mathrm{Ge}-$ $(1)-\mathrm{C}(2)-\mathrm{Si}(3)=95.2(2), \mathrm{Ge}(1)-\mathrm{C}(2)-\mathrm{Si}(4)=109.0(3), \mathrm{Ge}(1)-$ $\mathrm{C}(2)-\mathrm{Si}(5)=117.4(3)$.

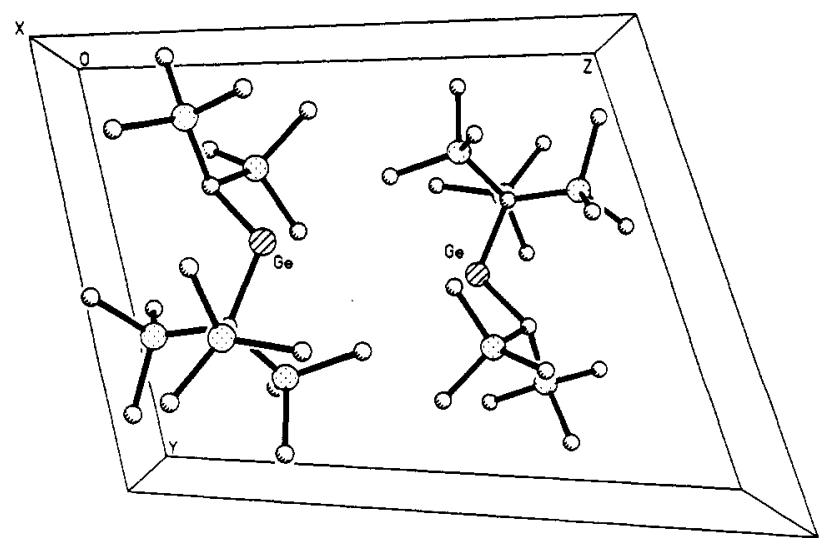

Figure 2. Unit cell diagram of $\left(\mathrm{Me}_{3} \mathrm{Si}\right)_{2} \mathrm{CHGeC}\left(\mathrm{SiMe}_{3}\right)_{3}$ (2).

dimerization is caused by a $\mathrm{Ge}-\mathrm{Ge}$ interaction that has been interpreted as a new type of double bond. ${ }^{7}$ Up to 
now, compound 1 still is the only known dialkylgermylene stable at ambient temperature.

Here we wish to report the synthesis and structure of $\left(\mathrm{Me}_{3} \mathrm{Si}\right)_{3} \mathrm{CGeCH}\left(\mathrm{SiMe}_{3}\right)_{2}(2)$, a stable dialkylgermylene that differs drastically from 1 in its solid-state structure.

According to our experience in germanocene and stannocene chemistry, ${ }^{8}$ a possible route to 2 was the nucleophilic substitution of a $\mathrm{Me}_{5} \mathrm{C}_{5}$ ligand in the $\pi$-complex $\mathrm{Me}_{5} \mathrm{C}_{5} \mathrm{GeCH}\left(\mathrm{SiMe}_{3}\right)_{2}$ (4). ${ }^{9}$ Thus, reaction of 4 with $\left(\mathrm{Me}_{3} \mathrm{Si}\right)_{3} \mathrm{CLi} \cdot 2 \mathrm{THF}^{10}$ affords, after subsequent workup, red-orange crystals of 2 in $65 \%$ yield. ${ }^{11}$ The germylene 2 is sensitive to air and moisture and soluble in aprotic solvents. It can be recrystallized from hexane. ${ }^{12}$

As proved by MS data, 2 is a monomer in the gas phase. Interestingly, the X-ray diffraction study shows that the monomeric structure is preserved also in the solid state (see Figure 1). ${ }^{13}$ The two alkyl ligands stabilize a V-shaped molecule with a bonding angle of $111.3^{\circ}$ at the $\mathrm{Ge}$ atom.

(7) (a) Hitchcock, P. B.; Lappert, M. F.; Miles, S. J.; Thorne, A. J. J. Chem. Soc., Chem. Commun. 1984, 481. (b) Goldberg, D. E.; Hitchcock, P. B.; Lappert, M. F.; Thomas, K. M.; Thorne, A. J.; Fjeldberg, T.; Healand, A.; Schilling, B. E. R. J. Chem. Soc., Dalton Trans. 1986, 2387. (c) Trinquier, G.; Malrieu, J. P.; Rivière, P. J. Am. Chem. Soc. 1982, 104, 4529.

(8) Jutzi, P.; Hielscher, B. Organometallics 1986, 5, 2511.

(9) Jutzi, P.; Hampel, B.; Hursthouse, M. B.; Howes, A. J. Organometallics 1986, 5, 1944.

(10) Eaborn, C.; Hitchcock, P. B.; Smith, J. D.; Sullivan, A. C. J. Chem. Soc., Chem. Commun. 1983, 827.

(11) A solution of (tris(trimethylsilyl)methyl)lithium-bis(tetrahydrofuran) $(6.71 \mathrm{~mL}, 3.89 \mathrm{mmol})$ in diethyl ether was added to a solution of $\mathrm{Me}_{6} \mathrm{C}_{6} \mathrm{GeCH}\left(\mathrm{SiMe}_{3}\right)_{2}(4 ; 1.43 \mathrm{~g}, 3.89 \mathrm{mmol})$ in diethyl ether at $-80^{\circ} \mathrm{C}$. Warming the mixture to room temperature gave a red-orange solution and a colorlees precipitate. After the mixture was stirred for an additional $36 \mathrm{~h}$ at room temperature, the solvent was evaporated and the residue was extracted with hexane. Concentrating and cooling yielded 1.16 $(65 \%)$ of red-orange crystals, mp $103^{\circ} \mathrm{C}$, which were filtered and dried in vacuo. ${ }^{1} \mathrm{H} \mathrm{NMR}\left(\mathrm{C}_{6} \mathrm{D}_{8}\right): \delta 3.41(8,1 \mathrm{H}, \mathrm{CH}), 0.35\left(8,27 \mathrm{H}, \mathrm{C}\left(\mathrm{SiMe}_{3}\right)_{3}\right)$ $0.25\left(\mathrm{~s}, 18 \mathrm{H}, \mathrm{CH}(\mathrm{SiMe})_{2}\right)$. ${ }^{13} \mathrm{C} \mathrm{NMR}\left(\mathrm{C}_{6} \mathrm{D}_{6}\right): 855.67\left(\mathrm{CH}\left(\mathrm{SiMe}_{\mathrm{g}}\right)_{2}\right), 47.54$ $\left(\mathrm{C}\left(\mathrm{SiMe}_{3}\right)_{3}\right), 5.42\left(\mathrm{C}(\mathrm{SiMe})_{3}\right), 3.46\left(\mathrm{CH}(\mathrm{SiMe})_{3}\right)$. ${ }^{20 \mathrm{Si}} \mathrm{NMR}\left(\mathrm{C}_{6} \mathrm{D}_{6}\right):$ $-6.60,-6.98 \mathrm{MS}\left(\mathrm{m} / \mathrm{z}\right.$ (relative intensity, \%)): $464\left(8, \mathrm{M}^{+}\right), 449\left(4, \mathrm{M}^{+}\right.$ - Me), $391\left(6, \mathrm{M}^{+}-\mathrm{SiMe}_{3}\right), 305\left(33, \mathrm{M}^{+}-\left(\mathrm{Me}_{3} \mathrm{Si}\right)_{2} \mathrm{CH}\right), 233\left(20, \mathrm{M}^{+}\right.$ $\left(\mathrm{Me} \mathrm{Si}_{3} \mathrm{C}\right), 73\left(100, \mathrm{Me}_{3} \mathrm{Si}^{+}\right)$. Anal. Calcd for $\mathrm{C}_{17} \mathrm{H}_{46} \mathrm{Si}_{5} \mathrm{Ge}\left(M_{\mathrm{r}} 463.57\right)$ : C, 44.05; H, 10.00. Found: C, 42.18; H, 9.38 .

(12) Crystals of 2 suitable for $\mathrm{X}$-ray diffraction measurements were grown by cooling a hexane solution very slowly to $-70^{\circ} \mathrm{C}$.

(13) Crystallographic data for 2: $\mathrm{C}_{17} \mathrm{H}_{46} \mathrm{GeSi}_{5}$, triclinic, space group PI $a=9.277$ (3) $A, b=12.151$ (4) $A, c=15.668$ (5) $A, \alpha=65.97(3)^{\circ}$ $\beta=63.87(2)^{\circ}, \gamma=65.63(2)^{\circ}, V=1388.5(8) A^{3}, d_{c a l c}=1.109 \mathrm{Mg} / \mathrm{m}^{3}, Z$ = 2. Data were collected on a Siemens $\mathrm{R} 3 \mathrm{~m} / \mathrm{V}$ diffractometer with graphite-monochromated Mo K $\alpha$ radiation $(\lambda=0.71073 \AA)$. An ab sorption correction was applied (semiempirical); the structure was solved by direct methods and refined by full-matrix least squares to a residual of $R=4.99 \%$ for 4665 observed reflections with $F>4.0 \sigma(F)$ in the range $4.0^{\circ}<2 \theta<54.0^{\circ}$ with use of Siemens SHELXTL PLUS (VMS). Complete details of the refinement and tables of data are available as supplementary material. Furthermore, the X-ray crystal structure data for 2 have been deposited at the Fachinformationszentrum Karlsruhe, D-7514 Eg. genstein-Leopoldshafen, Germany, under the number CSD-55 131.
The germanium-carbon distances are $2.012 \AA$ for $\mathrm{Ge}-\mathrm{CH}$ $\left(\mathrm{SiMe}_{3}\right)_{2}$ and $2.067 \AA$ for $\mathrm{Ge}-\mathrm{C}\left(\mathrm{SiMe}_{3}\right)_{3}$. The shortest distance between the two Ge centers is $5.704 \AA$, indicating that there is no bonding interaction between these atoms (Figure 2). Furthermore, the orientation of the germylene monomers excludes such an interaction.

We believe that steric reasons are responsible for the monomeric structure of 2 . In Lappert's germylene 1 , one of the two bis(trimethylsilyl)methyl ligands at each $\mathrm{Ge}$ center has to adopt a conformation in which the $\mathrm{C}-\mathrm{H}$ bond is oriented in the direction of the $\mathrm{Ge}-\mathrm{Ge}$ bond, thus minimizing repulsive effects between the two monomer units and allowing a weak bonding interaction (bond energy 20 $\left.\mathrm{kJ} \mathrm{mol}^{-1}\right){ }^{6 \mathrm{~b}}$ In the germylene 2 , a conformation comparable to that found in 1 is not possible. The additional trimethylsilyl group in the $\left(\mathrm{Me}_{3} \mathrm{Si}\right)_{3} \mathrm{C}$ ligand forces the $\left(\mathrm{Me}_{3} \mathrm{Si}\right)_{2} \mathrm{HC}$ ligand in a position with a trimethylsilyl group being in the direction of a hypothetical $\mathrm{Ge}-\mathrm{Ge}$ bond. In this orientation a $\mathrm{Ge}-\mathrm{Ge}$ bonding interaction is prohibited by steric requirements.

In the crystal structure of 2 a disorder is observed, which is caused by a rotation of the $\left(\mathrm{Me}_{3} \mathrm{Si}\right)_{3} \mathrm{C}$ ligand around the $\mathrm{Ge}-\mathrm{C}$ bond. ${ }^{14}$ This rotation does not have steric consequences, due to the high symmetry of this ligand. On the other side, the $\left(\mathrm{Me}_{3} \mathrm{Si}\right)_{2} \mathrm{HC}$ ligand remains in a fixed position; this is in accord with the steric constraints in this molecule.

Comparable to the synthesis of 2 , we have prepared the germylene $\mathrm{Me}_{3} \mathrm{SiCH}_{2} \mathrm{GeCH}\left(\mathrm{SiMe}_{3}\right)_{2}$ (3) by reaction of 4 with $\mathrm{Me}_{3} \mathrm{SiCH}_{2} \mathrm{Li}$. This compound is stable only up to -20 ${ }^{\circ} \mathrm{C}$ and has been trapped in form of its $[2+4]$ cycloaddition product (5) with 2,3-dimethylbutadiene. ${ }^{15}$

In a comparison of the dialkylgermylenes 1,2 , and 3 , it is evident that the number of trimethylsilyl groups in the alkyl ligands drastically influences the thermal stability and the solid-state structure of this class of compounds.

Supplementary Material Available: Listings of crystal data and structure determination and refinement details, atomic coordinates and isotropic thermal parameters, bond lengths and angles, and anisotropic thermal parameters for compound 2 ( 9 pages); a listing of observed and calculated structure factors (22 pages). Ordering information is given on any current masthead page.

(14) The molecule shown in Figure 1 has an abundance of $86 \%$. The other $14 \%$ of the molecules possess a $\left(\mathrm{Me}_{3} \mathrm{Si}\right)_{3} \mathrm{C}$ ligand rotated about $40^{\circ}$ around the $\mathrm{Ge}-\mathrm{C}$ axis.

(15) $\mathrm{C}_{17} \mathrm{H}_{43} \mathrm{GeSi}_{3}(5)$ : ${ }^{1} \mathrm{H}$ NMR $\left(\mathrm{CDCl}_{3}\right) \delta 1.67\left(\mathrm{~m}, 10 \mathrm{H}, \mathrm{C}_{6} \mathrm{H}_{10}\right), 0.05$ $\left(\mathrm{s}, 18 \mathrm{H}, \mathrm{CH}(\mathrm{SiMe})_{2}\right),-0.04\left(\mathrm{~s}, 9 \mathrm{H}, \mathrm{CH}_{2} \mathrm{SiMe}\right) ;{ }^{13} \mathrm{C}$ NMR $\left(\mathrm{C}_{0} \mathrm{D}_{j}\right) \delta 130.92$ $(\mathrm{C}=\mathrm{C}), 30.41\left(\mathrm{CH}_{2}\right), 19.58(\mathrm{CMe}), 3.05\left(\mathrm{CH}(\mathrm{SiMe})_{2}\right), 1.26\left(\mathrm{CH}_{2} \mathrm{SiMe}_{3}\right)$; ${ }^{29}$ Si NMR (CDCl $)_{3}$ \& $\delta .40,-0.19$; MS $(\mathrm{m} / \mathrm{z}$ (relative intensity, \%)): 402 $\left(2, \mathrm{M}^{+}\right), 320\left(5, \mathrm{M}^{+}-\mathrm{C}_{6} \mathrm{H}_{10}\right), 305\left(10, \mathrm{M}^{+}-\mathrm{C}_{6} \mathrm{H}_{10}-\mathrm{CH}_{3}\right), 73(100$ $\mathrm{SiMe}_{3}^{+}$. 